\title{
PEMBUATAN BUBUR INSTAN BERAS MERAH DENGAN PENAMBAHAN TEPUNG KACANG MERAH UNTUK MENINGKATKAN NILAI GIZI MP ASI
}

\author{
[Production of Brown Rice Instant Porridge with Addition of Red Bean Flour to Increase Nutritional Value of Breast Milk \\ Substitute]
}

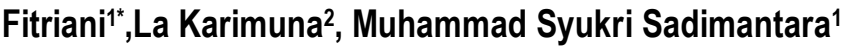

1 Jurusan IImu dan Teknologi Pangan,Fakultas Pertanian, Universitas Halu Oleo,Kendari

2Jurusan Agroteknologi,Fakultas Pertanian, Universitas Halu Oleo,Kendari

*Email: Fitrianis7395@gmail.com.Telp: +62082187027395

Diterima tanggal 08 Juli 2019

Disetujui tanggal 27 Juli 2019

\begin{abstract}
This study aimed to determine the effect of brown rice flour (Oryza nivara) and red bean flour (Vigna angularis $L$ ) formulations on organoleptic assessment, iron content, and proximate values of breast milk substitute. This study used a completely randomized design (CRD) consisting of five levels of red bean flour addition $(B 0=0 \%, B 110 \%, B 2=20 \%, B 3=$ $30 \%$, and B4 $=40 \%)$. Data analysis was carried out using the analysis of variance (ANOVA) method and then followed with Duncan's multiple range test (DMRT) with a $95 \%$ confidence level $(\alpha=0.05)$. The best result was obtained by $B 2$ treatment (addition of 20\% red bean flour) with assessment scores of color, aroma, taste, and texture reached 4.17 (like), 4.13 (like), 3.90 (like), and 3.96 (like), respectively. The selected treatment contained $11.53 \%$ water, $1.28 \%$ ash, $15.9 \%$ fat, $3.295 \%$ protein, $35.43 \%$ carbohydrate, and $1.341 \%$ iron. The results show that the addition of red bean flour had a very significant effect on the organoleptic improvement of color, aroma, and texture, and significantly increased the organoleptic characteristics of taste. The organoleptic assessment result shows that the product was favored by the panelists. Instant brown rice porridge with the addition of red bean flour met the standard of SNI No. 01-7111.1-2005 for fat, ash, and protein contents.

Keywords: red rice flour instant porridge, red bean flour, nutritional value, Iron
\end{abstract}

\section{ABSTRAK}

Penelitian ini bertujuan untuk menentukan pengaruh formulasi tepung beras merah (Oryza nivara) dan tepung kacang merah (Vigna angularisL) terhadap penilaian organoleptik, kandungan zat besi, dan nilai proksimat makanan pendamping ASI. Penelitian ini menggunakan rancangan acak lengkap (RAL) yang terdiri dari 5 jenis perlakuan yaitu penambahan tepung kacang merah yaitu $(B 0=0 \%, B 110 \%, B 2=20 \%, B 3=30 \%$ dan $B 4=40 \%)$. Analisis data dilakukan dengan metode analysis of varian (ANOVA) dengan uji lanjut Duncan's multiple range test (DMRT) dengan taraf kepercayaan $95 \%(a=0,05)$. Hasil penelitian terbaik bubur instan berbasis tepung beras merah yaitu perlakuan B2 (penambahan tepung kacang merah 20\%) dengan skor penilaian terhadap warna sebesar 4,17 (suka), aroma sebesar 4,13 (suka), rasa sebesar 3,90 (suka), tekstur sebesar 3,96 (suka), kadar air sebesar 11,53\%, kadar abu sebesar 1,28\%, kadar lemak sebesar 15,9\%, kadar protein sebesar $3,295 \%$ dan kadar karbohidrat sebesar $35,43 \%$, zat besi $1,341 \%$. Berdasarkan hasil penelitian penambahan tepung kacang merahberpengaruh sangat nyata terhadap peningkatan organoleptik warna, aroma, dan tekstur, dan berpengaruh nyata terhadap penimgkatan karakteristik organoleptik rasa bubur instanberbasis tepung beras merah terbaik, penilaian organoleptik dapat diterima dan disukai oleh panelis. Bubur instan beras merah dengan penambahan tepung kacang merah untuk kadar lemak, abu, dan protein telah memenuhi standar SNI No. 01-7111.1-2005.

Kata kunci: Bubur instan tepung beras merah, tepung kacang merah, nilai gizi, zat besi 


\section{PENDAHULUAN}

Masa bayi dan balita merupakan masa yang paling penting dalam perkembangan manusia, karena pertumbuhan dan perkembangan pada periode ini akan mempengaruhi kualitas seseorang di masa mendatang. Asupan gizi pada masa bayi dan balita perlu diperhatikan dan dipersiapkan dengan baik. Guna memenuhi kebutuhan gizi selain ASI, kepada bayi/anak mulai umur 6 bulan sampai 24 bulan diberikan makanan pendamping ASI (MPASI) dalam bentuk makanan atau minuman bergizi (SNI 01-7111.1-2005). Meskipun secara umum terjadi penurunan zat gizi per kilogram berat badan, pertambahan berat badan yang terjadi pada usia ini menyebabkan total kehidupan energi dan zat gizi meningkat, Sementara itu, bayi pada usia enam bulan telah siap secara fisiologis dan psikologis unutuk menerima berbagai jenis makanan dan kebiasaaan makanan sesuai dengan etnis, budaya, dan ekonomi setempat (Gamble et al., 2008).

Bubur merupakan makanan dengan tekstur yang lunak sehingga mudah untuk dicerna. Bubur dapat dibuat dari beras, kacang merah, ataupun dari beberapa campuran penyusun. Pengolahan bubur dilakukan dengan memasak bahan penyusun dengan air, (bubur nasi), mencampurkan santan, (bubur kacang merah), dan mencampurkan susu, (bubur susu), ( Larasati, 2011).

Perkembangan zaman menyebabkan masyarakat menuntut segala sesuatu yang serba cepat dan praktis. Demikian pula dalam hal makanan, masyarakat cenderung lebih menyukai produk pangan yang berbentuk instan. Bubur instan merupakan bubur yang telah mengalami proses pengolahan lebih lanjut sehingga dalam penyajiannya tidak diperlukan proses pemasakan. Penyajian bubur instan dapat dilakukan hanya dengan menambahkan air panas ataupun susu, sesuai dengan selera (Fellows dan Ellis, 1992).

Beras merah merupakan bahan pangan yang memilikikomponen penyusun yang dibutuhkan oleh tubuh. Komponen-komponen tersebut antara lain karbohidrat, zat besi, antioksidan, dan vitamin. Beras merah kurang banyak dimanfaatkan oleh orang meskipun memiliki komponen- komponen penyusun yang sangat dibutuhkan tubuh karena tekstur beras merah yang sangat keras dibandingkan beras putih.Beras merah Wakawondu merupakan beras merah local berasal dari Buton Utara Sulawesi Tenggara. Jenis beras merah lokal ini baik bagi kesehatan tubuh yang di jadikan untuk pembuatan produk bubur instan sehat, hal ini karena kandungan gizi beras merah per 100 gram, terdiri atas protein, 7,5 g, lemak $0,9 \mathrm{~g}$, karbohidrat 77,6, kalsium, $16 \mathrm{mg}$, fosfor $163 \mathrm{mg}$, zat besi, 0,3 g, vitamin B1 0,21 mg (Indriyani, 2013).

Keunggulan varietas Wakawondu yaitu memiliki aroma yang lebih harum dibandingkan dengan beras merah yang lain. Selain aroma lebih harum, wakawondu juga lebih pulen, sehingga dapat digunakan dalam pembuatan bubur instan. Sehingga diharapkan akan dihasilkan tekstur yang baik dan aroma yang menarik pada produk bubur instan beras merah. Kacang merah merupakan sumber karbohidrat, protein nabati, serat, zat besi, 
mineral seperti (fosfor, kalsium, mangan, besi, tembaga, serta natrium) dan vitamin (vitamin A, vitamin B1, vitamin dijadikan solusi lain dalam penggunaan beras merah. Saraswati (2016) pada penelitian sebelumnya, menggunakan tepung beras merah sebagai bahan pangan kue seroja. Selain itu pada penelitianya sebelumnya olehFebryanto (2016) menunjukan bahwa tepung beras merah dapat digunakan sebagai bahan pengganti tepung beras putih.

Keunggulan dari kacang merah adalah bebas kolesterol, sehingga aman untuk konsumsi oleh semua golongan masyarakat dari berbagaikelompok umur (Astawan, 2009). Kacang merah memiliki banyak manfaat seperti mencegah kolestrol jahat dan memperlancar pencernaaan (anti sembelit) dan membantu pematangan sel darah merah, membantu sintesa DNA dan RNA, serta menurunkan level hemosistein dan pembuluh arteri sehingga mengurangi resiko penyakit jantung dengan kandungan folat dan vitamin B6 (Rahmat et al., 2009).

Penelitian yang dilakukan oleh Ekawati (1999), menyatakan bahwa bubur bayi dengan substitusi tepung kacang merah menghasilkan kadar protein yang lebih tinggi dibandingkan dengan bubur bayi komensial. Oleh karena itu penelititertarik mengembangkan produk dengan memanfaatkan tepung beras merah dan kacang merah sebagai bahan baku pembuatan bubur instan sebagai makanan pendamping ASI. Berdasarkan uraian di atas, maka dilaporkan penelitian kajian pengaruh formulasi tepung beras merah dan kacang merah terhadap penilaian organoleptik dan kandungan proksimat pada bubur instan dengan tujuan untuk memberikan alternatif produk makanan selingan yang bernilai fungsional.

\section{BAHAN DAN METODE}

\section{Bahan}

Bahan yang digunakan dalam penelitian ini adalah beras merah (Oryza nivara) Wakawondu dan kacang merah (Phaseolus vulgaris L) yang telah dibeli di pasar Lombe Bagian Buton Tengah, susu bubuk skim, gula halus, aluminium foil, label dan air. Bahan kimia yang akan dibutuhkan untuk menganalisis kadar air, kadar abu, kadar lemak, kadar protein, dan kadar karbohidrat antara lain $\mathrm{H}_{2} \mathrm{SO}_{4}$ (teknis), $\mathrm{NaOH}$ (teknis), $\mathrm{K}_{2} \mathrm{SO}_{4}$ (teknis), $\mathrm{HNO}_{3}$ (teknis), $\mathrm{HCL}$ (teknis), alkohol 96\% (teknis).

\section{TahapanPenelitian}

\section{Pembuatan Tepung Beras Merah (Purba et al., 2017)}

Beras merah dibersihkan dari gabah dan kotoran kemudian direndam, ditiris, lalu di keringkan dengan alat oven.Dihaluskan dengan menggunakan alat blender dan diayak dengan menggunakan ayakan 80 mesh. Kemudian pada tahap akhir tepung beras merah disangrai. 


\section{Pembuatan Tepung Kacang Merah (Pangastuti et al.,2013 termodifikasi)}

Tahap pertama dalam pembuatan tepung kacang merah adalah direndam dengan air pada suhu kamar dalam waktu 48 jam dan terdapat penggantian air setiap 12 jam, kemudian dicuci dengan air mengalir, ditiriskanselama 15-20 menit, kemudian dikeringkan menggunakan alat oven dengan suhu $60^{\circ} \mathrm{C}$ kemudian dihaluskan dengan menggunakan alat blender, kemudian diayak dengan ukuran 80 mesh dan didapatkan tepung kacang merah.

\section{Pembuatan Bubur Instan (Yustiani, 2013 termodifikasi)}

Pembuatan bubur instan dilakukan dengan mencampur bahan-bahan yaitu tepung beras merah, tepung kacang merah,susu bubuk skim,dan gula halus. Proses pencampuran dilakukan dengan mengocok bahan berdasarkan urutan tujuan ini dimaksudkan untuk menghasilkan campuran bubur yang homogen.

\section{Penilaian Organoleptik}

Penentuan organoleptik produk bubur instan yang paling disukai panelis dari setiap perlakuan dilakukan dengan penilaian organoleptik terhadap produk meliputi warna, aroma, tekstur, dan rasa dengan menggunakan skala hedonik (5= sangat suka, 4= agak suka, 3= suka, 2= tidak suka, dan 1= sangat tidak suka). Pengujian dilakukan dengan 30 orang panelis tidak terlatih ( Setyaningsi et al., 2010).

\section{Analisis Nilai Gizi}

Analisis cookies yang proksimat yang meliputi analisiskadar air dengan menggunakan metode Thermogravimetri (AOAC, 2005), kadar abu menggunakan metode pengabuan kering (AOAC, 2005), kadar protein menggunakan metode Biuret (AOAC, 2005), kadar lemak menggunakan metode ekstrasi soxhlet (AOAC, 2005) dan analisis karbohidrat yang dihitung berdasarkan by difference (Winarno,2008).

\section{Rancangan Penelitian}

Penilitian ini menggunakan rancangan lengkap (RAL) yang terdiri atas satu faktor yakni formulasi tepung beras merah dan tepung kacang merah dalam pembuatan bubur instan (B), dengan perlakuan perbandingan masing-masing yaitu B0 (Tepung Beras Merah100\% : Tepung Kacang Merah0\%), B1 (Tepung Beras Merah 90\%: Tepung Kacang Merah 10\%), B2 (Tepung Beras Merah80\% : Tepung Kacang Merah20\%), B3 (Tepung Beras Merah70\% : Tepung Kacang Merah30\%) dan B4 (Tepung Beras Merah 60\%: Tepung Kacang Merah40\%). Setiap perlakuan diulang sebanyak tiga kali sehingga diperoleh 15 unit percobaan. Rancangan ini berdasarkan penelitian pendahuluan.

\section{Analisis Data}

Data yang di hasilkan dari penelitian ini dari hasil uji organoleptik. Data dianalisis menggunakan analisis sidik ragam (ANOVA) untuk menilai penerimaan panelis terhadap bubur instan yang meliputi warna, tekstur, aroma 
dan rasa produk bubur instan. Analisis data berpengaruh nyata dilanjutkan dengan uji duncan's multiple range test (DMRT) pada taraf kepercayaan 95\%( $\alpha=0,05)$.

\section{HASIL DAN PEMBAHASAN}

\section{UjiOrganoleptik}

Hasil analisis ragam (ANOVA) produk bubur instan pembuatan tepung beras merah Wakawondu dengan penambahan tepung kacang merah terhadap uji organoleptik dan nilai gizi bubur instan yang meliputi penilaian warna, aroma, rasa, dan tekstur.

Tabel 1. Rekapitulasi analisis sidik ragam pembuatan tepung beras merah Wakawondu dengan penambahan tepung kacang merah terhadap uji organoleptik dan nilai gizi pada bubur instan yang meliputi penilaian warna, aroma, rasa dan tekstur.

\begin{tabular}{ccc}
\hline No & Variabel pengamatan & Hasil uji F \\
\hline 1 & Uji hedonik warna & $* *$ \\
2 & Uji hedonik rasa & $*$ \\
3 & Uji hedonik aroma & $* *$ \\
4 & Uji hedonik tekstur & $* *$ \\
\hline
\end{tabular}

Keterangan: $\quad$ * = Berpengaruh nyata, ${ }^{* *}=$ Berpengaruh sangat nyata

Berdasarkan hasil analisis ragam pada Tabel 1 menunjukkan bahwa pembuatan tepung beras merah Wakawondu dengan penambahan tepung kacang merah terhadap uji organoleptik dannilai giziproduk berpengaruh sangat nyata terhadap penilaian organoleptik warna, aroma, dan tekstur. Penilian analisis ragam dari variabel pengamatan nilai organoleptik tekstur menunjukkan perlakuan yang diberikan berpengaruh nyata untuk nilai organoleptik rasa.

\section{Warna}

Hasil uji lanjut duncan multiple range test (DMRT) pengaruh penambahan tepung kacang merah terhadap penilaian organoleptik warna bubur instan berbasis tepung beras merah disajikan pada Tabel 2.

Tabel 2. Rerata hasil penilaian panelis terhadap organoleptik warna bubur instan tepung beras merah dan kacang merah.

\begin{tabular}{ccc}
\hline Perlakuan (TBM:TKM) $(\%)$ & Rerata Organoleptik Warna & Kategori \\
\hline B0 $(100: 0)$ & $2,93^{\mathrm{b}} \pm 0,90$ & Agak Suka \\
B1 $(90: 10)$ & $3,21^{\mathrm{b}} \pm 0,81$ & Agak Suka \\
B2 $(80: 20)$ & $4,17 \mathrm{a} \pm 0,62$ & Suka \\
B3 $(70: 30)$ & $3.11^{\mathrm{b}} \pm 0.93$ & Agak Suka \\
B4 $(60: 40)$ & $2,84 \mathrm{~b} \pm 0,95$ & agak Suka \\
\hline
\end{tabular}

Keterangan: Angka-angka yang diikuti oleh huruf yang berbeda menunjukan berbeda nyata berdasarkan uji DMRT 0,05 taraf kepercayaan 95\%, Tepung beras merah (TBM), Tepung kacang merah (TKM). 
Berdasarkan Tabel 2 tingkat kesukaan panelis terhadap parameter warna bubur instan berkisar antara 2,84-4,17. Penilaian panelis tertinggi terhadap parameter warna di peroleh pada perlakuan B2 (80\% Tepung beras merah : 20\% Tepung kacang merah)dengan nilai rata-rata 4,17. Hal ini diduga produk bubur instan yang dihasilkan berwarna coklat muda dipengaruhi oleh bahan baku dimana semakin banyak tepung kacang merah dalam formulasi, maka semakin coklat atau coklat kemerahan warna bubuk bubur bayi instan. Senyawa dalam kacang merah yang menyebabkan warna kemerahan tersebut adalah antosianin (Rukmana, 2009). Selain bahan baku, proses pengolahan juga diduga mempengaruhi warna bubur bayi instan (Fernando, 2008). Pada saat pengeringan, kandungan gula di dalam bubur bayi instan akan mengalami karamelisasi, selain itu juga terjadi reaksi maillard antar gula pereduksi dengan asam amino,sehingga menghasilkan warna yang lebih coklat.

\section{Aroma}

Hasil uji lanjut Duncan multiple range test (DMRT) pengaruh penambahan tepung kacang merah terhadap penilaian organoleptik aroma bubur instan berbasis tepung beras merah disajikan pada Tabel 3.

Tabel 3. Rerata hasil penilaian panelis terhadap organoleptik aroma bubur instan tepung beras merah dan kacang merah.

\begin{tabular}{ccc}
\hline Perlakuan (TBM:TKM) $(\%)$ & Rerata Organoleptik Aroma & Kategori \\
\hline B0 $(100: 0)$ & $3,03^{\mathrm{b}} \pm 0,84$ & Agak Suka \\
B1 $(90: 10)$ & $3,01^{\mathrm{b}} \pm 0,77$ & Agak Suka \\
B2 $(80: 20)$ & $3,90^{\mathrm{a}} \pm 0,72$ & Suka \\
B3 $(70: 30)$ & $3.08^{\mathrm{b}} \pm 0,69$ & Agak Suka \\
B4 (60: 40$)$ & $2,96 \mathrm{~b} \pm 0,76$ & Agak Suka \\
\hline
\end{tabular}

Keterangan: Angka-angka yang diikuti oleh huruf yang berbeda menunjukan berbeda nyata berdasarkan uji DMRT

0,05 taraf kepercayaan 95\%, Tepung beras merah (TBM), Tepung kacang merah (TKM).

Berdasarkan Tabel 3 tingkat kesukaan panelis terhadap parameter aroma bubur instan berkisar antara 2,96-3,90. Penilaian panelis tertinggi terhadap parameter aromadi peroleh pada perlakuan B2 (80\% Tepung beras merah : 20\% Tepung kacang merah) dengan nilai rata-rata 3,90. Hal ini diduga karena semakin tinggi konsentrasi kacang merah yang ditambahkan dalam formulasi, semakin agak langu aroma bubur bayi instan yang dihasilkan. Bau langu pada kacang merah disebabkan oleh enzim lipoksigenase (Kartikasari, 2006).

\section{Rasa}

Hasil uji lanjut duncan multiple range test (DMRT) pengaruh penambahan tepung kacang merah terhadap penilaian organoleptik rasa bubur instan berbasis tepung beras merah disajikan pada Tabel 4.

Tabel 4. Rerata hasil penilaian panelis terhadap organoleptik rasa bubur instan tepung beras merah dan kacang merah.

\begin{tabular}{ccc}
\hline Perlakuan (TBM:TKM) $(\%)$ & Rerata Organoleptik Rasa & Kategori \\
\hline B0 $(100: 0)$ & $3.12^{\mathrm{b}} 0,87$ & Agak Suka
\end{tabular}




$\begin{array}{llc}\text { B1 }(90: 10) & 3.24^{b} \pm 0,81 & \text { Agak Suka } \\ \text { B2 }(80: 20) & 4,13^{a} \pm 0,72 & \text { Suka } \\ \text { B3 }(70: 30) & 2,99^{b} \pm 0,73 & \text { Agak Suka } \\ \text { B4 }(60: 40) & 3,07^{b} \pm 0,78 & \text { Agak Suka }\end{array}$

Keterangan: Angka-angka yang diikuti oleh huruf yang berbeda menunjukan berbeda nyata berdasarkan uji DMRT 0,05 taraf kepercayaan 95\%, Tepung beras merah (TBM), Tepung kacang merah (TKM).

Berdasarkan Tabel 4 tingkat kesukaan panelis terhadap parameter rasabubur instan berkisar antara 2,99_ 4,13. Penilaian panelis tertinggi terhadap parameter rasa di peroleh pada perlakuan B2 (80\% Tepung beras merah : 20\% Tepung kacang merah) dengan nilai rata-rata 4,13. Adanya perlakuan tersebut diduga disebabkan oleh kombinasi antara tepung beras merah dan tepung kacang merah. Rasa pada bubur bayi instan dipengaruhi oleh adanya penambahan tepung kacang merah.. Selain itu, rasa manis pada bubur bayi instan disebabkan oleh adanya penambahan gula pasir dan susu skim. Sesuai penelitian Fatimah et al. (2013) susu memiliki fungsisebag ai pembentuk flavor dan bahan pengisi dan pengikat air. Susu bubuk lebih banyak digunakan karena penanganan nya dan mempunyai daya simpan yang cukup lama. Winarno (2008) melaporkan bahwa bahwa bahan pangan umumnya tidak terdiri dari satu rasa tetapi merupakan gabungan dari berbagai cita rasa yang utuh.

\section{Tekstur}

Hasil uji lanjut duncan multiple range test (DMRT) pengaruh penambahan tepung kacang merah terhadap penilaian organoleptik tekstur bubur instan berbasis tepung beras merah disajikan pada Tabel 5 .

Tabel 5. Rerata hasil penilaian panelis terhadap organoleptik tekstur bubur instan tepung beras merah dan kacang merah.

\begin{tabular}{ccc}
\hline Perlakuan (TBM:TKM) $(\%)$ & Rerata Organoleptik Tekstur & Kategori \\
\hline B0 $(100: 0)$ & $3,21^{\mathrm{b}} \pm 0,83$ & Agak Suka \\
B1 $(90: 10)$ & $3.03^{\mathrm{b}} \pm 0,83$ & Agak Suka \\
B2 $(80: 20)$ & $3.96^{\mathrm{a}} \pm 0,78$ & Suka \\
B3 $(70: 30)$ & $2,88^{\mathrm{b}} \pm 0,78$ & Agak Suka \\
B4 $(60: 40)$ & $2,91^{\mathrm{b}} \pm 0,74$ & Agak Suka \\
\hline
\end{tabular}

Keterangan: Angka-angka yang diikuti oleh huruf yang berbeda menunjukan berbeda nyata berdasarkan uji DMRT 0,05 taraf kepercayaan 95\%, Tepung beras merah (TBM), Tepung kacang merah (TKM).

Berdasarkan Tabel 5 tingkat kesukaan panelis terhadap parameter teksturbubur instan berkisar antara 2,88-3,96. Penilaian panelis tertinggi terhadap parameter tekstur di peroleh pada perlakuan B2(80\% Tepung beras merah : 20\% Tepung kacang merah) dengan nilai rata-rata 3,96. Hal ini di sebapkanTekstur dari suatu produk diduga dipengaruhi oleh bahan baku yang digunakan. Selain itu, proses pengayakan bubur bayi instan yang kurang halus diduga dapat menyebabkan tekstur berpasir pada bubur bayi instan (Elvizahro, 2011). 


\section{Analisis Gizi}

Berdasarkan hasil uji organoleptik, maka dapat ditentukan bahwa bubur instanterpilih terdapat pada perlakuan B2dengan komposisi (80\% tepung beras merah: 20\% tepung kacang merah), yang dibandingkan dengan perlakuan kontrol (100\% tepung beras merah : $0 \%$ tepung kacang merah). Dari perlakuan uji organoleptik bubur instan terpilih maka dapat dilakukan analisis proksimat meliputi kadar air, kadar abu, kadar lemak, kadar protein, dan kadar karbohidrat. Adapun nilai gizi yang didapatkan yaitu dapat dilihat pada Tabel 6 .

Tabel 6. Nilai analisis gizi produk bubur instan terpilih $\mathrm{BO}$ ( 0\% ) dan kontrol B2 $(80 \%)$

\begin{tabular}{|c|c|c|c|}
\hline $\begin{array}{c}\text { Komponen } \\
(\%)\end{array}$ & $\begin{array}{c}\text { B0 (Bubur Instan } \\
\text { Kontrol) }\end{array}$ & $\begin{array}{c}\text { B2 (Bubur Instan } \\
\text { Terpilih) }\end{array}$ & ${ }^{*} \mathrm{SNI}(\%)(\mathrm{mg})$ \\
\hline Air & $11,53 \mathrm{a} \pm 0,50$ & $12,01^{b} \pm 0,13$ & Maksimum. 4 \\
\hline Abu & $1,283 a \pm 0,26$ & $1,189^{\circ} \pm 0,06$ & Maksimum. 3 \\
\hline Protein & $3,295 \mathrm{a} \pm 0,11$ & $3,629 b \pm 0,03$ & Minimum. 8 \\
\hline Lemak & $15,90 a \pm 0,59$ & $15,87^{\mathrm{b}} \pm 1,23$ & Minimum. 6-15 \\
\hline Karbohidrat & $31,432^{a} \pm 3,08$ & $32,275^{b} \pm 3,34$ & Maksimal. 77 \\
\hline $\mathrm{Fe}$ & $0,609 a \pm 0,37$ & $1,341^{\mathrm{b}} \pm 2,21$ & $5 \mathrm{mg}$ \\
\hline
\end{tabular}

Berdasarkan Tabel 6 memberikan informasi bahwa nilai proksimat bubur instantepung beras merah dengan penambahan tepung kacang merah perlakuan B0 memiliki nilai tertinggi pada kadar abu sebesar 1,283\%, nilai terendah kadar abu B2 1,189\%, kadar lemak perlakuan B0 sebesar 15,90\%, sedangkan terendah perlakuan B2 15,87\%, kadar protein perlakuan B2 sebesar 3,629\% dan nilai terendah pada perlakuan B0 3,269\%namun memiliki kadar air terendah perlakuan B0 sebesar 11,53\% sedangkan nilai tertinggi terdapat pada perlakuan B2 12,01\% kadar karbohidrat pada perlakuan B2 sebesar 32,27\% sedangkan pada perlakuan B0 31,432\% dan zat besi perlakuan B2 1,341\% sedangkan perlakuan B0 sebesar 0,609\%. Pada uji T perlakuan B0 (Tepung kacang merah 0\%: Tepung beras merah 100\%) berbeda nyata terhadap perlakuan B2 (Tepung kacang merah 10\% : Tepung beras merah 90\%).

\section{Kadar Air}

Berdasarkan Tabel 6 hasil analisis gizi bubur instandari perlakuan terpilih. Kadar air bubur instantertinggi $\mathrm{B}_{2}$ (80\% tepung beras merah : $20 \%$ tepung kacang merah) dengan nilai rata-rata kadar air bubur instan sebesar $(12,01 \%)$. Kadar air bubur bayi instan meningkat dengan bertambahnya konsentrasi tepung kacang merah, hal ini diduga disebabkan oleh kandungan protein yang terdapat pada tepung kacang merah. Berdasarkan penelitian Mappiratu (2012), tepung yang memiliki kandungan protein yang lebih tinggi bersifat menyerap air lebih kuat dibandingkan tepung dengan kandungan protein yang rendah. Kadar air bubur bayi instan beras merah dengan penambahan tepung kacang merah yang dihasilkan berkisar antara 11,53 - 12,01\%. Spesifikasi MP-ASI bubuk 
instan oleh SNI 01-7111.1-2005, menetapkan kadar air dalam $100 \mathrm{~g}$ MP-ASI adalah tidak lebih dari $4 \mathrm{~g}$. Kadar air berhubungan erat dengan daya simpannya ( Astawan 2009). Pembuatan bubur instan beras merah dengan penambahan tepung kacang merah memiliki kadar air yang lebih tinggi dibanding SNI. Akibat hal tersebut maka diduga daya simpan bubur bayi instan tidak lebih lama dari bubur bayi yang memenuhi standar air SNI, disebabkan tingginya kadar air akan menyediakan media untuk tumbuhnya mikroorganisme (Earle, 1982 ).

\section{Kadar Abu}

Berdasarkan Tabel 6 hasil analisis gizi menunjukkan kadar abu bubur instanberas merahdengan tanpa penambahan tepung kacang merah tertinggi B0 (100\% tepung beras merah) tanpa penambahan kacang merah dengan nilai rata-rata kadar abu sebesar (1,283\%). Berdasarkan hasil analisis kadar abu terhadap bubur bayi instan menunjukkan bahwa semakin tinggi konsentrasi tepung kacang merah dalam bubur bayi instan, semakin tinggi pula kadar abu yang terkandungnya (Koswara, 2013). Berdasarkan penelitian Prabowo (2010), bahwa kadar abu bubur bayi instan beras merah dengan penambahan tepung kacang merah berkisar memiliki nilai B0 $(1,283 \%)$ nilai ratarata kadar abu bubur bayi instan tersebut memenuhi dari standar MP-ASI bubuk instan yang ditetapkan oleh SNI 017111.1-2005, dimana syarat kadar abu pada MP ASI yang tidak boleh melebihi 3,5 g per $100 \mathrm{~g}$. (Haryadi 2006) melaporkan bahwa gelatinisasi pati terjadi karena pemasakanyakarena keberadaan air.

\section{Kadar Protein}

Berdasarkan Tabel 6 hasil analisis gizi bubur instan dari perlakuan terpilih. Kadar protein bubur instantertinggi B2 (80\% tepung beras merah : 20\% tepung kacang merah) nilai rata-rata kadar protein bubur instan sebesar (3,629\%) sedangkan kadar protein bubur instan nilai terendah terdapat pada perlakuan B0 (100\% : tepung beras merah) dengan nilai nilai rata-rata (3,29\%). Syarat mutu bubur bayi instan yang ditetapkan oleh SNI 017111.1-2005, Kadar protein untuk bubur bayi instan minimal adalah $8 \%$ (b/b).Dengan demikian, kadar protein memenuhi syarat mutu. Hal ini diduga disebapkan oleh perbedaan bahan baku dan proses pengolahanya .Hal ini sesuai dengan penelitian yang dilakukan oleh Composite (2013) dimana pada pembuatan bubur instan dilakukan pencampuran secara kering. Metode pencampuran kering dapat meminimalkan zat gizi bubur instan termasuk kadar proteinya (Hendy, 2007).

\section{Kadar Lemak}

Berdasarkan Tabel 6 hasil analisis gizi bubur instandari perlakuan terpilih. Kadar lemak bubur instantertinggi $\mathrm{B} 0(100 \%$ tepung beras merah) tanpa penambahan kacang merah dengan nilai rata-rata kadar lemak bubur instan sebesar $(15,90 \%)$ sedangkan kadar lemak bubur instan nilai terendah terdapat pada perlakuan B2 ( $80 \%$ : tepung beras merah : $20 \%$ tepung kacang merah) dengan nilai rata-rata $(15.87 \%)$. Berdasarkan hasil penelitian Kustiani, 2013 kandungan lemak pada tepung kacang merah yang di gunakan lebih tinggi dibandingkan 
kandungan lemak yang ada pada tepung beras merah. Sehingga kadar lemak pada bubur instandipengaruhi oleh tingginya kandungan lemak pada kacang merah. Menurut syarat mutu bubur bayi instan yang ditetapkan oleh SNI 01-7111.1-2005, Kadar protein untuk bubur bayi instan minimal adalah 6-15\%). Dengan demikian, kadar lemak pada bubur instan memenuhi syarat mutu. Hal ini sesuai dengan penelitianKrisnatuti dan Yenrina (2002), kadar lemak pada bubur instan beras merah meningkat, hal ini diduga karena disebapkan kandungan lemak tepung kacang merah.Menurut penelitian Haryatiet al. (2018), total konsumsi lemak tidak boleh melebihi dari 30\% dari total energi dan total konsumsi lemak jenuh tidak melebihi $10 \%$ dari total energi. Jadi, perlu diingat bahwa pangan berlemak harus dikonsumsi lebih bijaksana.

\section{Kadar Karbohidrat}

Berdasarkan Tabel 6 hasil analisis gizi bubur instandari perlakuan terpilih. Kadar karbohidrat bubur instantertinggi B2(80\% tepung beras merah : 20\% tepung kacang merah) dengan nilai rata-rata kadar karbohidrat bubur instan sebesar $(32,27 \%)$ sedangkan kadar lemak bubur instan nilai terendah terdapat pada perlakuan B0 (100\% : tepung beras merah) tanpa penambahan kacang merah dengan nilai rata-rata $(31,43 \%)$. Hal ini diduga disebabkan adanya penambahan sedikit tepung kacang merah dan ini juga dikarenakan kandungan karbohidrat tepung beras merah tinggi. Hal ini sesuai dengan penelitian Kustyawati et al.(2012), bahwa kadar karbohidrat yang dihitung secara by difference dipengaruhi oleh komponen zat gizi lain, semakin tinggi komponen zat gizi lain maka kadar karbohidrat akan semakin rendah, dalam hal ini zat gizi lain adalah lemak yang berasal dari RPO. Kadar karbohidrat menurun dengan bertambahnya konsentrasi tepung kacang merah. Hal ini diduga disebabkan kandungan karbohidrat tepung kacang merah $(12,83 \mathrm{~g})$ lebih rendah. Bubur bayi instan memiliki kadar karbohidrat berkisar dari 63,02\% hingga 66,82\%. Spesifikasi SNI 017111.12005 tenta ng MP ASI bubuk instan mensyaratkan kandungan karbohidrat < $30 \mathrm{~g}$ dalam $100 \mathrm{~g}$ MPASI. Pramata et al. (2014) mengatakan karbohidrat bubur bayi instan lebih tinggi maka diduga akan menimbulkan kegemukantumpukan lemak.

\section{Kandungan Zat Besi(Fe)}

Berdasarkan hasil penelitian pada Tabel 6, rerata kadar Fe bubur instan tertinggi adalah perlakuan B2 adalah $1,34 \%$ dan yang terendah pada perlakuan $\mathrm{B} 0$ dengan rerata $0,69 \%$. Hal ini diduga karena pada perlakuan B2 terdapat penambahan tepung kacang merah sebagai sumber Fe ( Grueger 2013). Hal ini sesuai dengan penelitian El Obeid et al,(2009), bahwa kadar Fe semakin meningkat dengan semakin besarnya konsentrasi kacang merah yang ditambahkan. Kadar Fe B0 lebih rendah jika dibandingkan dengan B2 hal ini diduga karena pada pada perlakuan B0 tidak ada penambahan tepung kacang merah. Hal ini sesuai dengan penelitian Andarwulan et al. (2013), bahwa produk bubur instan dengan penambahan tepung kacang merah $0 \%$ masih 
mengandung kadar Fe disebabkan karena bahan pembuatan bubur instan mengandung Fe walaupun dalam juml ah sedikit.

\section{KESIMPULAN}

Terdapat pengaruh perbedaan formulasi tepung beras merah terhadap tingkat kesukan panelis pada bubur instan. Perlakuan penambahan tepung kacang merah berpengaruh sangat nyata terhadap warna, aroma, dan tekstur ,berpengaruh nyata terhadap rasa.Bubur instan terpilih terbaik adalah (B2) dengan komposisi (tepung beras merah80\% : tepung kacang merah 20\%) yaitu warnamemiliki nilai sebesar 4,53 (suka), aroma memiliki nilai sebesar 3,90 ( suka), rasa memiliki nilai sebesar 4,13 (suka) dan tekstur memiliki nilai sebesar 3,96 (suka).Bubur instan terpilih terbaik memiliki nilai gizi pada bubur instan yaitu untuk karbohidrat $32,27 \%$, dan zat besi $1,341 \%$, kadar abu 1,189\%, kadar protein 3,629\%, kadar lemak 15,873\% dapat memenuhi standar SNI sedangkan pada kadar air tidak memenuhi standar SNI.

\section{DAFTAR PUSTAKA}

Astawan, M. 2009. Sehat dengan Hidangan Kacang dan Biji-Bijian. Penebar Swadaya. Jakarta.

Afriansyah, LH. 2007. Food Chemistry. AVI Publishing Co., Connecticut.

Andarwulan, Nuri dan Kusnandar, F. 2013. Analisis Pangan. Dian Rakyat. Jakarta.

Associaton of Official agricultural chemist (AOAC) 2005. Official Method of Analysis of Association of Official Agricultural Chemist. AOAC Inc. Washington D.C

Badan Standarisasi Nasional. 2005. (SNI) Standar Nasional Indonesia. Makanan Pendamping Air Susu Ibu Bagian 1. Bubuk InstanUbi Kayu. (SNI 01-7111.4-2005). Jakarta.

Badan Pusat Statistik. 2003. Laporan Hasil Survey Konsumsi Garam Yodium Rumah Tangga. Badan Pusat Statistik. Jakarta.

[BSN] Badan Standarisasi Nasional. 2005. SNI: 01-7111.1-2005. Makanan Pendamping Air Susu Ibu (MP-ASI)Bagian 2. Bubur Instan. Dewan Standar Nasional Indonesia. Jakarta.

Composite C. S. 2013. Formulasi Bubur Instan Menggunakan Komposit Tepung Kacang Merah. Jurnal gizi dan pangan 8(2), 95-102

Ekawati D. 1999. Pembuatan Cookies dari Tepung Kacang Merah (Phaseolus vulgaris L) Sebagai Makanan Pendamping ASI (MP-ASI). Skripsi. Fakultas Pertanian. Institut Pertanian Bogor. Bogor. 
Elvizahro. 2011. Kontribusi MP-ASI Bubur Bayi Instan dengan Substitusi Tepung Ikan Patin dan Tebu Labu Kuning terhadap Kecukupan Protein dan Vitamin A pada Bayi. Program Studi IImu Gizi, Fakultas Kedokteran, Universitas Diponegoro, Semarang.

Earle, R. L., 1982. Satuan Operasi Dalam Pengolahan Pangan. Sastra Budaya. Bogor.

El Obeid T, Fakhwari D, Berghofer E. 2009. Iron bioavailability and organoleptic properties of sorghum and white beans noodles. International Journal of Arts and Sciences 1(6):262-271.

Febriyanto. 2016. Pengaruh Substitusi Tepung Beras Merah Pada Pembuatan Kue Lapis Betas Terhadap Daya Terima Konsumen. Universitas Negeri Jakarta. Jakarta.

Fellow, P.J and Ellis. 1992. Food Processing Technology : Principles And Practice. Ellis Horwood England

Fernando , E. 2008. Food Processing Technology Princples and Practice. Ellis Horwood. London.

Fatimah, P. S., E. Nasution, dan E. Y. Aritonang. 2013. Uji Daya Terima dan Nilai Gizi Biskuit yang Dimodifikasi Dengan Tepung Kacang. Jurnal kesehatan masyarakat. 2 (6) : 1-7.

Gamble Y, Bunyapen C, Bhatia J. 2008. Feeding the term infant. Berdanier et al, Editor. Handbook of Nutrition and Food and Edition. New York: CRC Press.

Grueger B 2013 Weaning from the breast. Paediatr Child Health 18(4): 210.

Haryaty, N., Ansharullah., Asyik, N. 2018. Pengaruh Penambahan Tepung Beras Merah ( Oryza nivara) terhadap Uji Organoleptik dan Proksimat Bolu Kukus. Jurnal Sains Teknologi Pangan (JSTP). 3(1) : 1006-1017.

Haryadi. (2006). Teknologi Pengolahan Beras. Gadjah Mada University Press.

Indrasari B. 2005. Weaning from the breast. Paediatr Child Health, 18(4), 210.

Indriyani F, Hidaja N. dan Suryanto A. 2013. Karakteristik Fisik, Kimia dan Sifat Organoleptik Tepung Beras Merah Berdasarkan Variasi Lama Pengeringan. Jurnal Pangan dan Gizi. 4(8) : 27-34.

Kartikasari, O. 2006. The Application of Red Bean Flour in Red Bean Instant Soup: It's Physical, Chemical, and Sensory Evaluation. UKS. Semarang.

Krisnatuti, D. dan Yenrina R. 2006. Menyiapkan Makanan Pendamping ASI. Puspa Swara. Jakarta.

Kustyawati ME., Susilawati., Tobing D, Trimaryanto. 2012. Profil asam lemak dan asam amino susu kambing segar dan terfermentasi. J Teknol Industri Pangan XXIII (1):47-52.

Kustiani, A. 2013. Pengembangan crackers sumber protein dan mineral dengan penambahan tepung daun kelor (Moringa oleifera) dan tepung badankepala ikan lele dumbo (Clarias gariepinus). Fakultas Ekologi Manusia, Institut Pertanian Bogor. Bogor. 
Mappiratu. 2012. Teknologi Pangan. Tadulako University Press. Palu.

Purba, J.E., Nainggolan, R.J., dan Ridwansya. 2017. Karakterisasi Sifat Fisiko-Kimia dan Sensori Cookies dari Tepung Komposit (Beras Merah, Kacang Merah dan Mocaf). Jurnal Rekayasa Pangan dan Pertanian. 5 (2) : 302.

Pangastuti, H. A., Affandi D.R., Ishartina, D., 2013. Karakterisasi Sifat Fisik dan Kimia Tepung Kacang Merah (Phaseolus vulgaris L) Dengan Beberapa Perlakuan Pendahuluan. Jurnal Teknosains Pangan. 2(1) : 20 29.

Prabowo, Bimo. 2010. Kajian Sifat Fisikokimia Tepung Millet Kuning dan Tepung Millet Merah. Universitas Sebelas Maret Surakarta. Skripsi.

Rahmat, I. S., Yusmanizar, dan Melianda, K. 2009. Pengaruh Penggunaan Lapisan Edibel (edible coating), Kalsium Klorida, dan Kemasin Plastik Terhadap Mutu Nanas (Ananas comusus merr.) Terolah Minimal. Jurnal Teknologi dan Industri Pertanian Indonesian. 2(4) : 21-26.

Rukmana, H.R. 2009. Buncis. Penerbit Kanisius. Yogyakarta.

Rachmat A dan Agustina , F., 2007 . Pembuatan NataDe Coco dengan Fortifikasi Limbah Cucian Beras Menggunakan AcetobacterXylinum. Universitas di ponegoro. Semarang.

Setyaningsih D, Apriyantono A, dan Sari MP. 2010. Analisis Sensori untuk Industri Pangan dan Agro. IPB Press. Bogor

Shimelis EA, Rakshit SK. 2006. Effect of processing on antinutrient and in vitro protein digestibility of kidney bean (Phaseolus vulgaris L.) varieties grown in East Africa. Food Chemistry (103): 161-172.

Saraswati, Dwi. 2006. Pengaruh Penggunaan Santan Terhadap Kue Soraja Tepung Beras Merah. Universitas Negeri Jakarta. Jakarta.

Winarno, F.G., 2008. Kimia pangan dan gizi. Gramedia Pustaka Utama. Jakarta.

Yustiani, Budi, dan Setiawan 2013. Formulasi Bubur Instan Sumber Protein Menggunakan Komposit Tepung Kacang Merah ( Phaseolus vulgaris L) dan Pati Ganyong ( Canna Edulis Kerr) Sebagai Makanan Pendamping ASI (MP-ASI). Fakultas Ekologi Manusia, Institut Pertanian Bogor. 